\title{
POLYOL DEHYDROGENASES IN CANDIDA ALBICANS
}

\section{REDUCTION OF D-XYLOSE TO XYLITOL ${ }^{1}$}

\author{
L.A. VEIGA \\ Instituto de Bioquimica da Universidade Federal do Paraná \\ $e$ \\ Instituto do Biologia e Pesquisas Tecnológicas \\ P.O. Box 939, Curitiba, Paraná, Brazil
}

(Received November 24, 1967)

\begin{abstract}
Candida albicans grown in a liquid medium containing $0.5 \% \mathrm{D}$-xylose produced an adaptative NADP-polyol dehydrogenase which catalyzes the reversible reduction of some aldoses to the corresponding polyols. This enzyme was extracted from the culture and purified 134-fold using ammonium sulfate precipitations followed by calcium phosphate gel column chromatography. The Michaelis constant for D-xylose was determined to be $6.7 \times 10^{-3} \mathrm{M}$. Heating of the enzyme up to $43^{\circ}$ enhanced its activity, but it became completely inactive at $65^{\circ}$.
\end{abstract}

The respective reduction of $\mathrm{D}$-xylose and $\mathrm{L}$-arabinose to xylitol and $\mathrm{L}$ arabitol by an NADP-linked enzyme was found by VEIGA et al. $(1-4)$ in cellfree extracts of Candida albicans grown in the presence of D-xylose. Reports from CHIANG and KNIGHT (5) and Hers (6), on the other hand, involved aldose reductases respectively from filamentous fungus and seminal vesicle. MORET and SPERTI ( 7 ) showed the presence of a similar enzyme in Oospora lactis.

The enzymatic oxidation of xylitol to D-xylulose by a non-specific NADlinked polyol dehydrogenase was also found in Candida albicans by VEIGA et al. (1-4). ChaKRAVORTY et al. $(8)$ determined a similar enzyme in C. utilis, and CHIANG and KNIGHT (5) in a filamentous fungus. Fossit et al. (9) presented the data which indicates that Aerobacter aerogenes metabolizes xylitol through the route common to the other organisms, but a different sequence is involved in the metabolism of L-arabitol. Two xylitol dehydrogenases were determined by HoLLMANN and TOUSTER (10) and by HiCKMAN

Abbreviations: (NADP and NADPH) Nicotinamide adenine dinucleotide phosphate and its reduced form. (NAD and $\mathrm{NADH}$ ) nicotinamide adenine dinucleotide and its reduced form.

1 This work was supported in part by a grant GM. 11888 from the National Institutes of Health, U.S.A. 
and AsHwell (11) in animal tissue. One is NADP-linked and produces Lxylulose, and the other is NAD-linked and produces D-xylulose.

C. albicans contains dehydrogenases which catalyze the conversion of Dxylose to D-xylulose:

$$
\text { D-xylose } \stackrel{\mathrm{NADPH}}{\longrightarrow} \mathrm{xylitol} \stackrel{\mathrm{NAD}}{\longrightarrow} \mathrm{D} \text {-xylulose }
$$

The first of these enzymes is the subject of the present paper. The properties of the second are considered in a separate report.

Purification by column chromatography of the NADP-linked enzyme obtained from this microorganism and its kinetic studies are also reported. Recently SCHER and HORECKER (12) have also described a similar enzyme system in C. utilis.

\section{MATERIALS AND METHODS}

Growth of cells. Candida albicans (ROBIN) Berkhout, 1923, phase S, sample 582 from Mackinon, was cultivated in a liquid medium containing the following components per liter : ammonium sulfate $2 \mathrm{~g}$; ammonium nitrate $1 \mathrm{~g} ; \mathrm{MgSO}_{4}$.

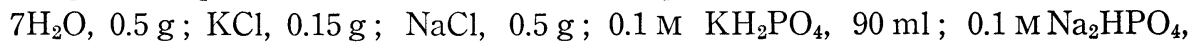
$10 \mathrm{ml} ; 10 \%$ aqueous solution $(\mathrm{w} / \mathrm{v}) \mathrm{CaCl}_{2}, 1 \mathrm{ml}$; and $17 \mathrm{ml}$ of a micronutrients solution containing $\mathrm{Fe}\left(\mathrm{NO}_{3}\right)_{3} \cdot 9 \mathrm{H}_{2} \mathrm{O}, 0.483 \mathrm{mg} ; \mathrm{ZnSO}_{4} \cdot 7 \mathrm{H}_{2} \mathrm{O}, 0.287 \mathrm{mg} ; \mathrm{MnSO}_{4}$. $\mathrm{H}_{2} \mathrm{O}, 0.396 \mathrm{mg}$; $\left(\mathrm{NH}_{4}\right)_{6} \mathrm{Mo}_{7} \mathrm{O}_{4} \cdot 4 \mathrm{H}_{2} \mathrm{O}, 0.402 \mathrm{mg} ; \mathrm{CuCl}_{2} \cdot 2 \mathrm{H}_{2} \mathrm{O}, 0.121 \mathrm{mg}$; yeast extract, $1 \mathrm{~g}$. $0.5 \% \mathrm{D}$-xylose was used as the sole carbon source.

After 20 hours of growth in a gyratory shaker at $28^{\circ}$ the cells were collected by centrifugation and washed twice with $0.1 \mathrm{M}$ phosphate buffer at $\mathrm{pH}$ 7.0. Then the cells were dried at $30^{\circ}$ and kept at $0-2^{\circ}$.

Lactobacillus plantarum (Orla-JENSEN, 1919) Holland, 1920, was grown in a medium containing Difco yeast extract, $5 \mathrm{~g}$; Difco nutrient broth, $10 \mathrm{ml}$; sodium acetate, $10 \mathrm{~g} ; \mathrm{MgSO}_{4} \cdot 7 \mathrm{H}_{2} \mathrm{O}, 0.1 \mathrm{~g} ; \mathrm{MnSO}_{4} \cdot 4 \mathrm{H}_{2} \mathrm{O}, 0.01 \mathrm{~g} ; \mathrm{NaCl}, 0.01 \mathrm{~g}$; $\mathrm{FeSO}_{4} \cdot 7 \mathrm{H}_{2} \mathrm{O}, 0.01 \mathrm{~g}$; D-xylose or L-arabinose, $10 \mathrm{~g}$; glucose, $1 \mathrm{~g}$; and distilled water in a total volume of one liter. The cell growth was carried out without aeration at $37^{\circ}$ for 24 hours. The cells were collected by centrifugation, washed twice with $0.2 \mathrm{M} \mathrm{NaHCO}$ and kept frozen.

Preparation of enzymes. All operations were performed at $0^{\circ}$ unless otherwise stated. The cell-free extract was prepared by autolysing $10 \mathrm{~g}$ of dried C. albicans in $30 \mathrm{ml}$ of $0.1 \mathrm{M} \mathrm{NaHCO}_{3}$ at $30^{\circ}$ for $10-15 \mathrm{hr}$. The autolysate was collected by centrifugation. The residue was washed with $30 \mathrm{ml}$ of $0.1 \mathrm{M}$ $\mathrm{NaHCO}_{3}$. The extracts and washings were combined ("crude extract", $38 \mathrm{ml}$ ) (see Table 1).

To the crude extract $(10 \mathrm{ml})$ ammonium sulfate $(2.42 \mathrm{~g})$ was gradually added. The precipitate was collected by centrifugation after $10 \mathrm{~min}$ in ice and dissolved in $3 \mathrm{ml}$ of distilled water (Fraction 1). To the supernatant solution was added $0.62 \mathrm{~g}$ more of ammonium sulfate under the same conditions. 
Table 1. Purification of NADP-linked polyol dehydrogenase from Candida albicans.

\begin{tabular}{l|c|r|r}
\hline \multicolumn{1}{c|}{ Fractions } & $\begin{array}{c}\text { Total activity } \\
\text { (units) }\end{array}$ & $\begin{array}{c}\text { Specific } \\
\text { Activity } \\
\text { (units/mg) }\end{array}$ & $\begin{array}{c}\text { Purification } \\
\text { (fold) }\end{array}$ \\
\hline Crude Extract & 5950 & 2.3 & - \\
Ammonium Sulfate (Fraction III) & 3000 & 11.2 & 5 \\
Calcium phosphate gel (Fraction 15) & 111 & 308.0 & 134 \\
\hline
\end{tabular}

The precipitate was collected by centrifugation and dissolved in $3 \mathrm{ml}$ of cold distilled water (Fraction II). To the supernatant solution was added $0.65 \mathrm{~g}$ more of ammonium sulfate, the precipitate was collected by centrifugation and dissolved in $3 \mathrm{ml}$ of distilled water (Fraction III). To the last supernatant solution was added $0.67 \mathrm{~g}$ more of ammonium sulfate, under the same conditions. The precipitate was collected by centrifugation and dissolved in $3 \mathrm{ml}$ of cold distilled water (Fraction IV).

Since the most active fraction for the NADP and the NAD-linked polyol dehydrogenases (13) were found in the Fraction III (Table 1), the enzyme fraction was further purified by calcium phosphate gel column chromatography (14). The calcium phosphate gel was packed into a chromatographic column $(10 \mathrm{~mm} \times 80 \mathrm{~mm})$ with pressure and buffered with $0.01 \mathrm{M}$ phosphate buffer $\mathrm{pH}$ 6.8. Exactly $2 \mathrm{ml}$ of Fraction III (dialyzed for $14 \mathrm{hr}$ against $1 \times 10^{-3} \mathrm{M}$ phosphate buffer $\mathrm{pH}$ 6.8) was applied to the column and eluted with stepwise increasing concentrations of phosphate buffers. The elution was carried out with $30 \mathrm{ml}$ of $0.02 \mathrm{M}, 40 \mathrm{ml}$ of $0.04 \mathrm{M}, 20 \mathrm{ml}$ of $0.07 \mathrm{M}, 20 \mathrm{ml}$ of $0.1 \mathrm{M}$ and $20 \mathrm{ml}$ of $0.2 \mathrm{M}$ phosphate buffer at $\mathrm{pH} 6.8$. The NADP-linked enzyme was found in the fractions 10-20 and the NAD-linked enzyme in the fractions 35-41 (13).

Enzyme activity and protein content (15) were measured in each fraction.

Cell-free extracts of Lactobacillus plantarum were prepared in a Nossal's shaker (16). To $8 \mathrm{ml}$ of cell suspension containing $1 \mathrm{~g}$ of frozen cells in $0.02 \mathrm{M} \mathrm{NaHCO}_{3}$ were added $8 \mathrm{~g}$ of glass beads and shaken thrice with refrigeration for 30 seconds each. Then the whole suspension was centrifuged. The supernatant was collected and the sediment was washed twice with $6 \mathrm{ml}$ of $0.02 \mathrm{M} \mathrm{NaHCO}_{3}$. All the supernatants were combined and kept frozen. This solution was used as the source of D-xylose isomerase and L-arabinose isomerase. D-Xylose isomerase was prepared from the cell-free extracts of L. plantarum according to BURMA and HORECKER (17), and L-arabinose isomerase according to HeATH et al. (18).

Lactic dehydrogenase was prepared from rabbit muscle by the method of KORNBERG (19).

Enzyme assay. Enzymatic activity was measured spectrophotometrically following either the reduction or the oxidation of NADP at $340 \mathrm{~m} \mu$. The different systems are shown in the tables and figures. From the crude 
extract and ammonium sulfate fractions, a suitable amount of the enzyme was taken and the enzyme activity measured within the range of exact proportionality of the measurements. The enzyme activities of fractions from the calcium phosphate gel column were measured for aliquots of $0.5 \mathrm{ml}$ of eluates. The reaction was begun by the addition of substrate. A unit of enzyme was defined as the quantity required to oxidize $1 \mu$ mole of $\mathrm{NADPH}$ per minute under the conditions of the assay.

Analysis. The protein contents of the crude extracts and of the ammonium sulfate fractions were assayed by the turbidimetric method of BücHER (20). The protein contents of fractions obtained by the column chromatography were assayed by the spectrophotometric method of WARBURG and CHRISTIAN (15), using the optical densities at 260 and $280 \mathrm{~m} \mu$.

Products of the reactions were determined by the following methods. Pentose formation was measured by the orcinol method of MEJBAuM (21). The ketopentoses were determined by the spectrophotometric method of DiscHE and Borenfreund (22). Paper chromatography was carried out in Whatman No. 1 chromatographic paper, using phenol-water as a solvent and alkaline silver nitrate (23) as a developing agent. D-Xylose was identified by the method of BURMA and HORECKER (17), and L-arabinose by the method of HEATH et al. (18).

Chemicals. Glass beads N. 12 were a gift from the Minnesota Mining and Manufacturing Co., Campinas, Brazil. The other chemicals were purchased from commercial sources.

\section{RESULTS}

\section{Purification of enzyme}

Enzyme was fractionated by the stepwise additions of ammonium sulfate. As seen in Table 1, the enzyme is mostly located in Fraction III. Calcium phosphate gel chromatography allowed the separation of the two enzymes, NADP-linked polyol dehydrogenase and NAD-linked (13) polyol dehydrogenase. Fig. 1 shows the results of the experiment concerning the purification of the NADP-linked enzyme. The NADP-linked enzyme, purified by column chromatography with calcium phosphate gel, showed a fairly good stability. When frozen it maintained its activity for months. The purification of the NADPlinked enzyme enhanced the activity by 134 -fold. Table 1 shows the purification data for this enzyme.

\section{Substrate specificity of NADP-polyol dehydrogenase}

In order to study the substrate specificity of the NADP-linked enzyme the reductions of D-xylose, L-arabinose, D-ribose, D-arabinose, D-lyxose, L-xylose, $\mathrm{D}$-glucose, D-galactose, D-mannose and D-fructose were carried out. The examination for reverse reaction was also tried with xylitol, L-arabitol, D-arabitol, D-mannitol, $i$-erythritol, D-sorbitol, dulcitol and ribitol. Table 2 and Table 3 


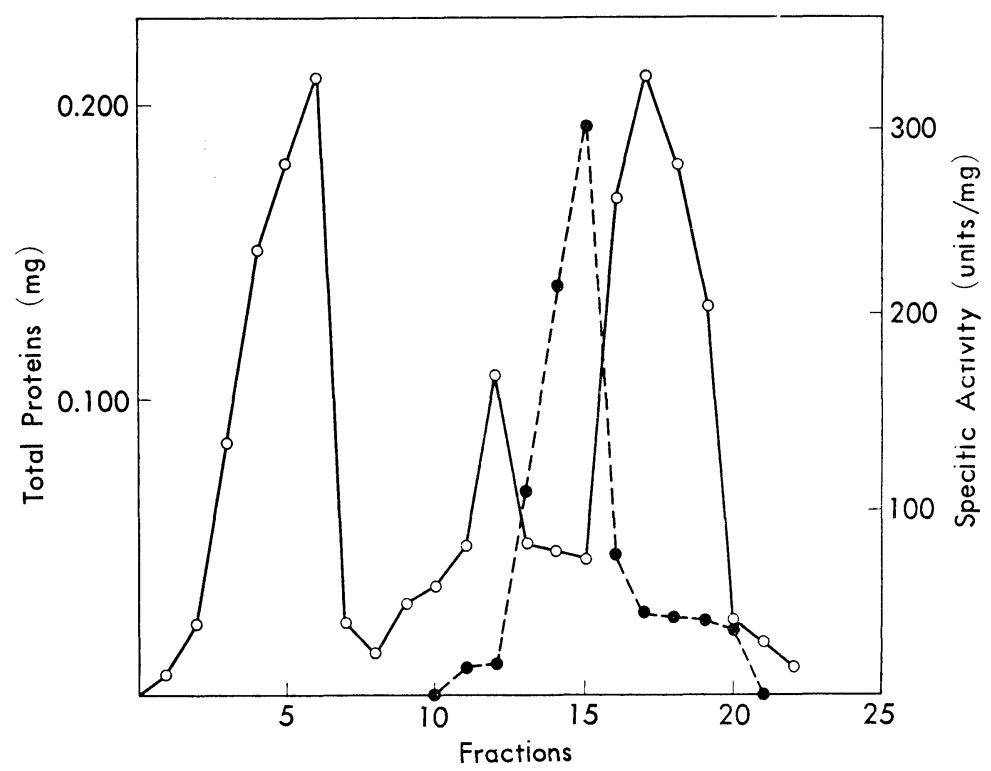

Fig. 1. Purification of NADP-polyol dehydrogenase of Candida albicans by calcium phosphate gel column chromatography.

The fractions were eluted with phosphate buffers $\mathrm{pH} 6.8$ at different concentrations. Fractions 1 to 10 were eluted with $0.02 \mathrm{M}$ buffer, and fractions $10-20$ with $0.04 \mathrm{M}$ buffer. The incubation mixtures $(3 \mathrm{ml})$ contained $1.7 \mathrm{ml}$ of water, $0.6 \mathrm{ml}$ of $0.1 \mathrm{M}$ glycylglycine buffer $\mathrm{pH} 7.4,0.1 \mathrm{ml}$ of $0.1 \mathrm{M} \mathrm{D}$-xylose, $0.1 \mathrm{ml}$ of $0.005 \mathrm{M} \mathrm{NADPH}$ and $0.5 \mathrm{ml}$ of enzyme.

Total proteins _. - Specific activity

show the results of these experiments.

\section{Reaction products}

Products of the reduction of pentoses. Xylitol was shown to be formed from $\mathrm{D}$-xylose in a system containing D-xylose and NADPH. In this experiment a mixture was prepared of $6.8 \mathrm{ml}$ of water; $2 \mathrm{ml}$ of $0.1 \mathrm{M}$ glycylglycine buffer $\mathrm{pH} 7.4 ; 0.5 \mathrm{ml}$ of $0.1 \mathrm{M} \mathrm{D}$-xylose; $0.5 \mathrm{ml}$ of $0.005 \mathrm{M} \mathrm{NADPH}$ and $0.2 \mathrm{ml}$ of Fraction III. The reaction mixture was incubated at $37^{\circ}$ for $40 \mathrm{~min}$. The activity of the enzyme was followed by spectrophotometrical changes in the optical densities at $340 \mathrm{~m} \mu$. Proteins were coagulated by heating in a boiling water bath and the resultant supernatant was treated with ion-exchange resin (Illco-Way Universal Model De-ionizer, Illinois Water Treatment Co.) to remove inorganic salts. The deionized solution was concentrated to small volume and then examined by paper chromatography. The spots were developed with alkaline silver nitrate reagent (Fig. 2). 
Table 2. Substrate specificity of NADP-polyol dehydrogenase from C. albicans ${ }^{x}$.

\begin{tabular}{l|c}
\hline \multicolumn{1}{c|}{ Substrates } & $\begin{array}{c}\% \text { activity } \\
\text { (D-xylose }=100 \%)\end{array}$ \\
\hline D-Xylose & 100 \\
L-Arabinose & 76 \\
D-Ribose & 71 \\
D-Galactose & 69 \\
D-Glucose & 36 \\
A-Arabinose & 13 \\
D-Lyxose & 11 \\
L-Sorbose & 6 \\
D-Mannose & 5 \\
L-Xylose & 5 \\
D-Fructose & 2 \\
\hline
\end{tabular}

a System : $0.05 \mathrm{ml}$ of $0.1 \mathrm{M}$ substrate, $0.05 \mathrm{ml}$ $\mathrm{NADPH}(3 \mathrm{mg} / \mathrm{ml}), 10$ units of $\mathrm{Ca}$ phosphate gelpurified enzyme (mixed fractions), $0.6 \mathrm{ml}$ of $0.1 \mathrm{M}$ glycylglycine buffer ( $\mathrm{pH} \mathrm{7.5),} \mathrm{in} \mathrm{a} \mathrm{total} \mathrm{volume}$ of $3 \mathrm{ml}$.

Table 3. Polyols as substrates of NADP-polyol dehydrogenase of C. albicans ${ }^{a}$.

\begin{tabular}{l|c}
\hline Polyols & $\begin{array}{c}\% \text { activity } \\
\text { (xylitol=100\%) }\end{array}$ \\
\hline Xylitol & 100 \\
Dulcitol & 121 \\
L-Arabitol & 105 \\
Sorbitol & 73 \\
Ribitol & 46 \\
Erythritol & 33 \\
Mannitol & 16 \\
D-Arabitol & 14 \\
\hline
\end{tabular}

a System: $0.05 \mathrm{ml}$ of $1 \mathrm{M}$ substrate, $0.05 \mathrm{ml}$ NADP $(3 \mathrm{mg} / \mathrm{ml}), 10$ units of $\mathrm{Ca}$ phosphate gelpurified enzyme (mixed fractions), $0.6 \mathrm{ml}$ of $0.1 \mathrm{M}$ glycine buffer $\mathrm{pH} 8.6$ in a total volume of $3 \mathrm{ml}$.

Products of oxidation of polyols. The formation of pentoses by the oxidation of polyols was demonstrated by incubating the following system for $30 \mathrm{~min}$ at $40^{\circ}: 6.8 \mathrm{ml}$ of water, $2 \mathrm{ml}$ of $0.1 \mathrm{M}$ glycine buffer $\mathrm{pH} 8.6,0.5 \mathrm{ml}$ of 


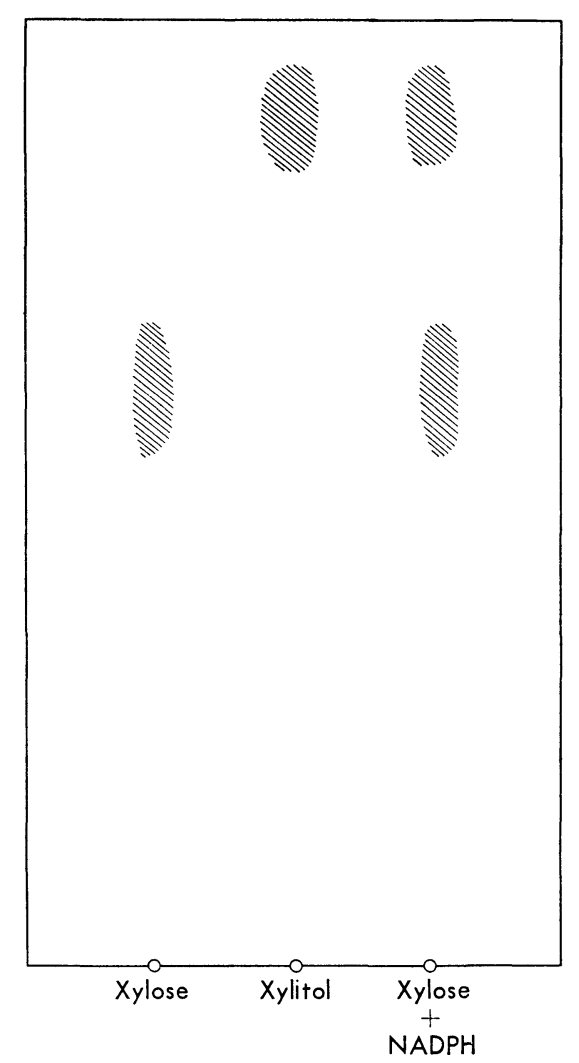

Fig. 2. Diagram of paper chromatogram showing the product of D-xylose reduction catalyzed by NADP-polyol dehydrogenase.

$1 \mathrm{M}$ polyol, $0.5 \mathrm{ml}$ of $0.005 \mathrm{M}$ NADP and $0.2 \mathrm{M}$ of Fraction III.

Proteins were coagulated by heating the reaction mixture in a boiling water bath. The supernatant after centrifugation was deionized with ionexchange resin in the same way as in the previous experiment. The deionized material was concentrated to a $1 / 20$ volume of the starting solution in a flash evaporator and analyzed for the products by paper chromatography (Fig. 3).

Orcinol reaction. Pentose formation from xylitol and L-arabitol upon incubation with Candida enzyme was also assayed by the following coupled system $^{1}$.

1 It is known that lactic dehydrogenase from rabbit muscle is dependent on NADP, however, NADPH can be substituted for NADH but reacts at less than $1 \%$ of the rate, according to MEHLER et al. (24). 


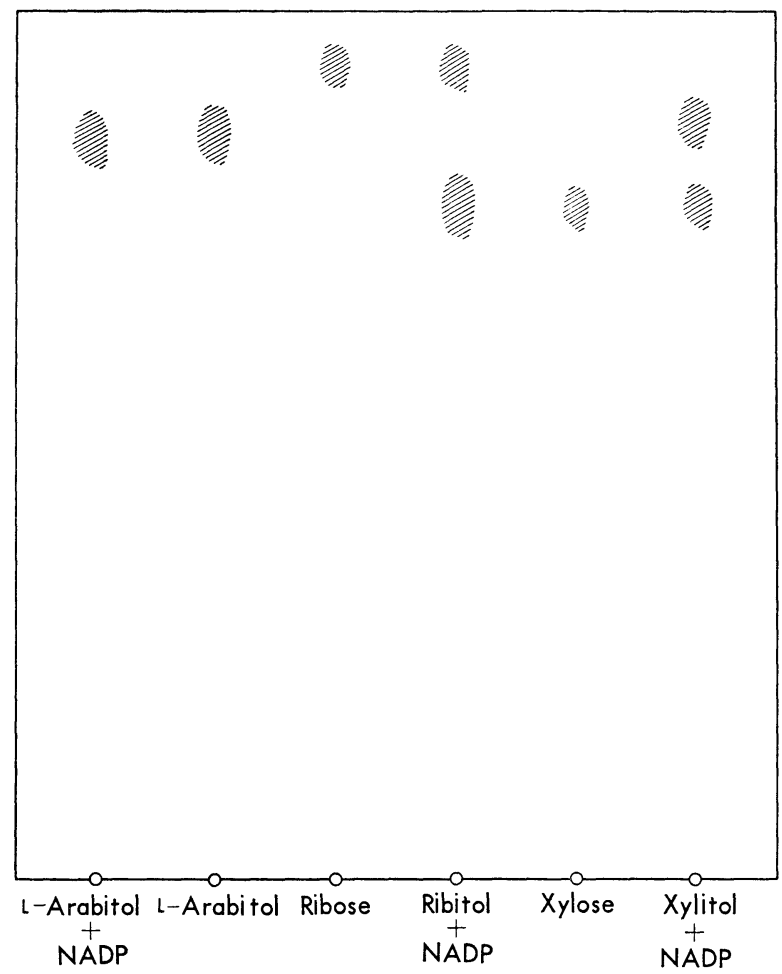

Fig. 3. Diagram of paper chromatogram showing the pentitolpentose reaction catalyzed by NADP.polyol dehydrogenase of Candida albicans.

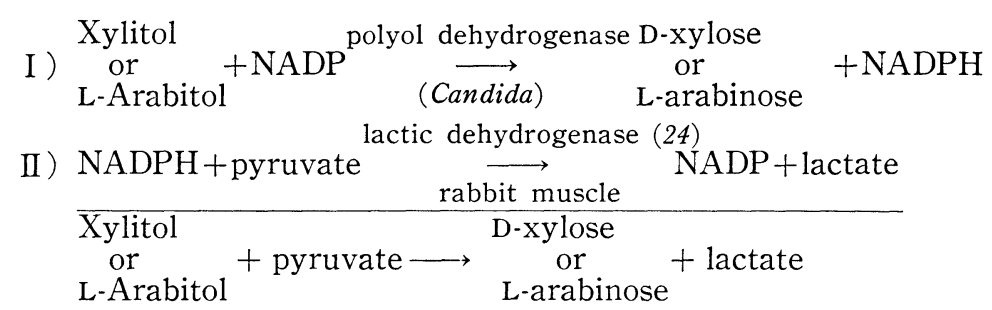

The reaction mixture used was composed of $0.1 \mathrm{ml}$ of $1 \mathrm{M}$ xylitol or $0.1 \mathrm{ml}$ $1 \mathrm{M} \mathrm{L}$-arabitol ; $0.1 \mathrm{ml}$ of $0.9 \mathrm{M}$ pyruvate; $0.2 \mu$ mole of NADP; $0.1 \mathrm{ml}$ of lactic dehydrogenase; $0.05 \mathrm{ml}$ of Candida enzyme (Fraction III); $0.2 \mathrm{ml}$ of $0.1 \mathrm{M}$ glycine buffer $\mathrm{pH} 8.6$; and $0.15 \mathrm{ml}$ of water. The mixture was incubated at $37^{\circ}$ for two hours and the reaction stopped by heating in a boiling water bath for about 15 seconds. Aliquots of these supernatants were removed for the 
Table 4. Orcinol assay for pentose formation from xylitol and L-arabitol.

\begin{tabular}{l|l|c}
\hline \multicolumn{1}{c|}{ Reaction } & \multicolumn{2}{|c}{$\mu$ moles of pentose formed } \\
\cline { 2 - 3 } & $1 \mathrm{hr}$ & $2 \mathrm{hr}$ \\
\hline With xylitol & 2.50 & 4.08 \\
With L-arabitol & 2.50 & 3.43 \\
Control (no xylitol or L-arabitol) & 0.80 & 0.80 \\
Standard (0.5 $\mu$ moles D-xylose) & & 0.27 \\
\hline
\end{tabular}

orcinol assay (Table 4).

\section{Assay with $\mathrm{D}$-xylose isomerase and L-arabinose isomerase}

The pentoses formed from xylitol and L-arabitol were assayed with $\mathrm{D}$-xylose isomerase (17) and L-arabinose isomerase (18) from Lactobacillus plantarum. Aliquots of the protein-free supernatant from the following enzymatic system were taken out and incubated with $\mathrm{D}$-xylose isomerase or L-arabinose isomerase of Lactobacillus plantarum. The incubation mixture contained $2 \mathrm{ml}$ of the protein-free supernatant (another aliquot of the same enzyme solution used for

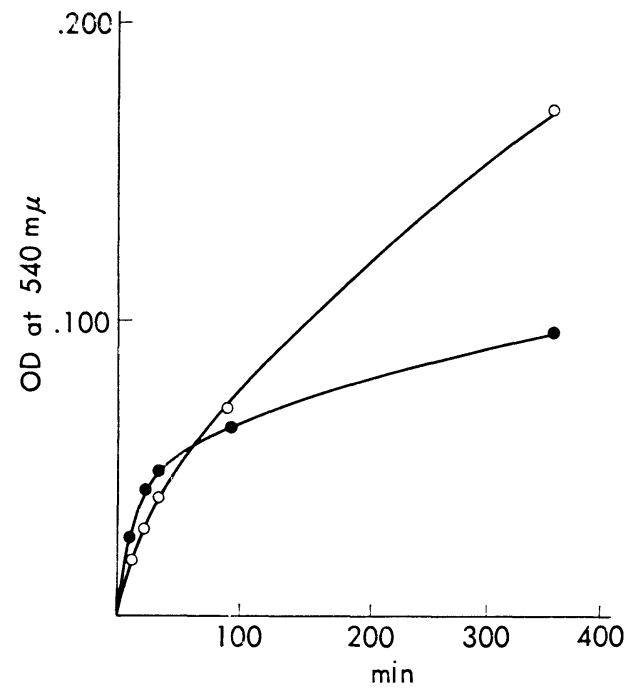

Fig. 4. Ketose formation by the action of D-xylose isomerase ( $\bigcirc$ ) and L-arabinose isomerase (0) from Lactobacillus plantarum on the reaction products obtained by the action of NADP-polyol dehydrogenase of C. albicans, determined by the cysteine-carbazole reaction. 


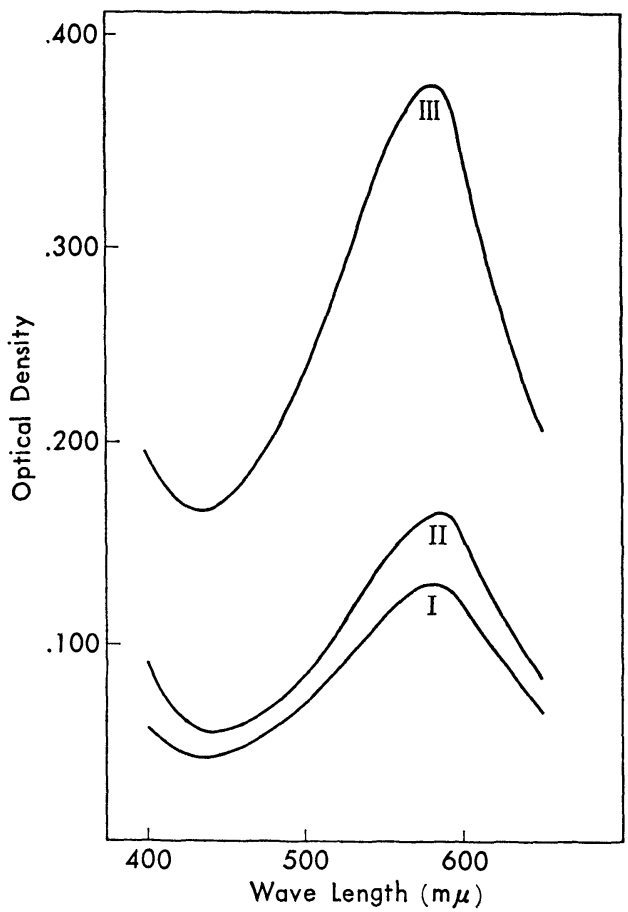

Fig. 5. The curves I, II and III show the absorption spectra after cysteine-carbazole test of aliquots of reaction mixtures shown in fig. 4 , taken out at each 0,10 and 30 min reaction time.

the orcinol assay); $1 \mathrm{ml}$ of borate buffer $\mathrm{pH} 8.2 ; 0.1 \mathrm{ml}$ of $\mathrm{D}$-xylose isomerase or L-arabinose isomerase solution; and $0.9 \mathrm{ml}$ of water. The reaction mixture was incubated at $37^{\circ}$ and $0.5 \mathrm{ml}$ aliquots were taken out at intervals of reaction time of $0,10,20,30,90$ and $360 \mathrm{~min}$ for cysteine-carbazole test, after being deproteinized with zinc sulfate and barium hydroxide (Fig. 4). Fig. 5 shows the absorption spectra of the cysteine-carbazole reaction after incubation of the pentose formed by D-xylose isomerase from Lactobacillus plantarum (17). The three curves were each obtained from aliquots of the reaction mixtures after 0,10 and $30 \mathrm{~min}$ incubation.

\section{Reaction products from D-glucose and D-galactose.}

The polyols formed by the action of the Fraction III from D-glucose and D-galactose as well as the aldoses formed from sorbitol and dulcitol were identified by paper chromatography according to the same procedure described for D-xylose and L-arabinose. Fig. 6 and Fig. 7 show the chromatographic analyses of these two experiments. 


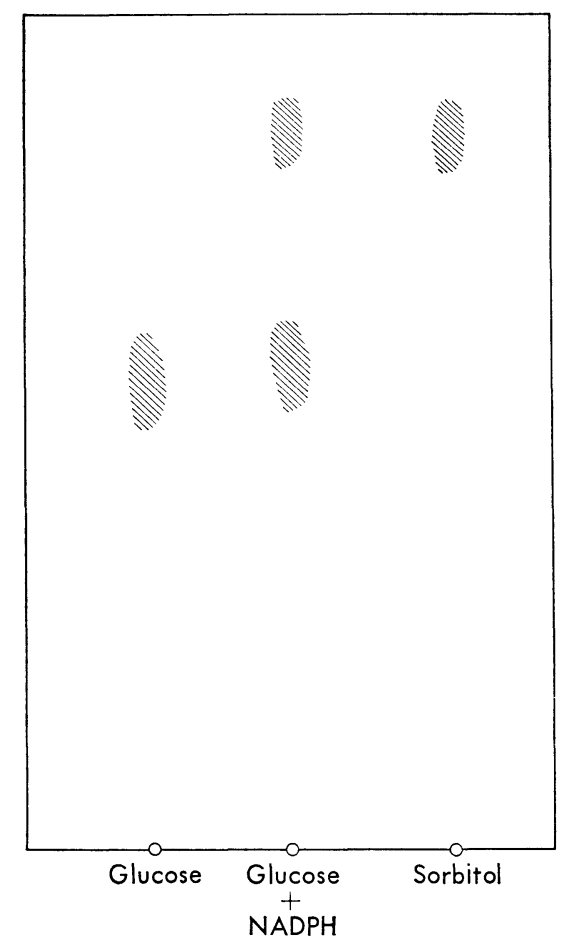

Fig. 6. Diagram of paper chromatogram showing the product by glucose reduction.

\section{Assay for xylose isomerase in Candida}

The assay procedure was based on the appearance of ketopentose, measured with the cysteine-carbazole test, with D-xylose or L-arabinose as substrate, as described by HEATH et al. (18). The reaction mixture $(1 \mathrm{ml})$ contained 10 $\mu$ moles of D-xylose or L-arabinose, $40 \mu$ moles of $0.1 \mathrm{M}$ Tris buffer, $\mathrm{pH} 7.5$, and increasing concentrations of Candida albicans extract $(40-120 \mu \mathrm{g})$ were incubated at $30^{\circ}$ for $10-20 \mathrm{~min}$. No ketopentoses were detected by the cysteinecarbazole test, even after $2 \mathrm{hr}$ at room temperature.

\section{Properties of NADP-linked polyol dehydrogenase}

It was found that this enzyme shows no striking $\mathrm{pH}$ dependence on the acid side for D-xylose $\rightarrow$ xylitol reaction, as will be clearly seen from Fig. 8 . In contrast, however, no enzyme activity was observed on the acid side for xylitol $\rightarrow D$-xylose reaction, and its optimal activity was found to be at a $\mathrm{pH}$ range from 8 to 10 .

The Michaelis constant for $\mathrm{D}$-xylose $\rightarrow$ xylitol reaction was determined according to the method of DIXON (25), giving a $K_{m}$ value of $6.7 \times 10^{-3} \mathrm{M}$ for 


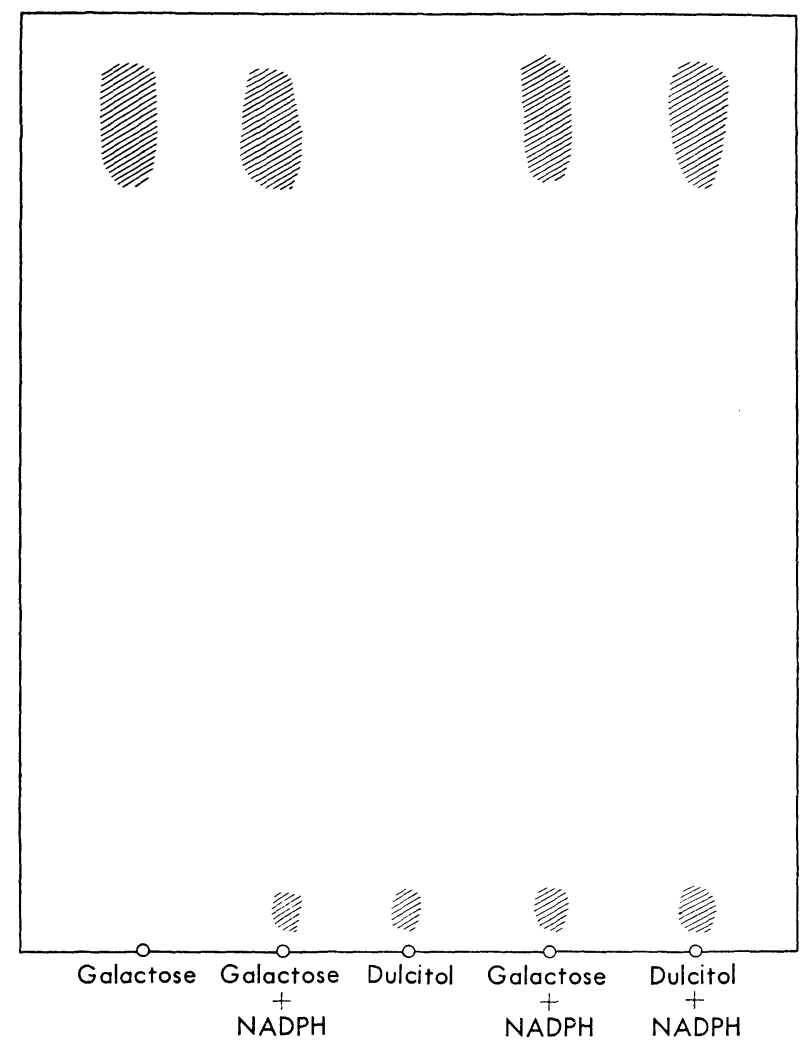

Fig. 7. Diagram of paper chromatogram showing the product by galactose reaction.

D-xylose.

The heating of the enzyme in $0.02 \mathrm{M}$ glycylglycine buffer at $\mathrm{pH} 7.4 \mathrm{up}$ to $43^{\circ}$ enhanced its activity. At $65^{\circ}$ the enzyme became completely inactive. In these experiments the enzyme solutions were first heated for $10 \mathrm{~min}$ and then assayed under the ordinary conditions (Fig. 9).

\section{DISCUSSION}

The first step in the metabolism of D-xylose by Candida albicans was found to be the reduction of this aldose to xylitol, catalyzed by a NADP-polyol dehydrogenase studied in the present paper. This appears to be an obligatory step in xylose metabolism since the direct isomerization of $\mathrm{D}$-xylose to $\mathrm{D}$ xylulose does not occur. 


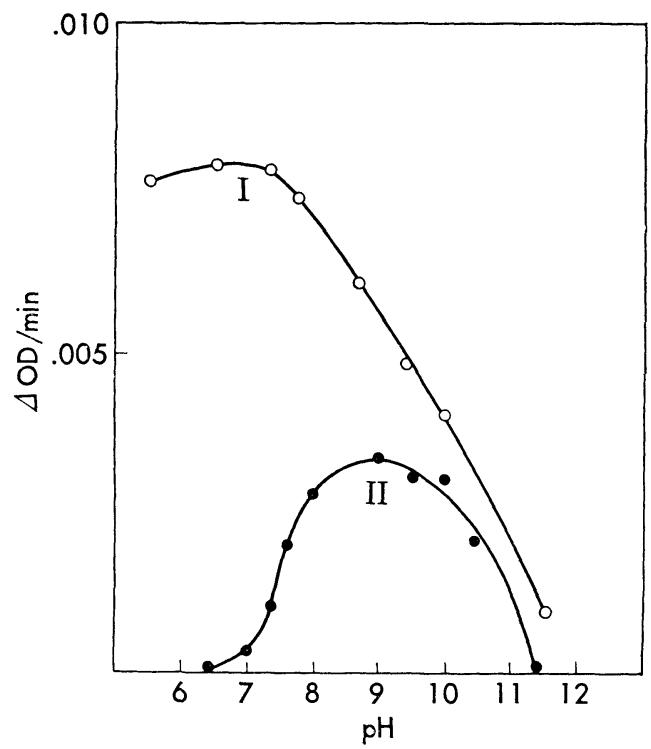

Fig. 8. Effect of $\mathrm{pH}$ on NADP-polyol dehydrogenase activity. Curve I shows the $\mathrm{pH}$ effect on D-xylose $\rightarrow$ xylitol reaction, and curve II shows the effect on xylitol $\rightarrow D \cdot x y l o s e$ reaction.

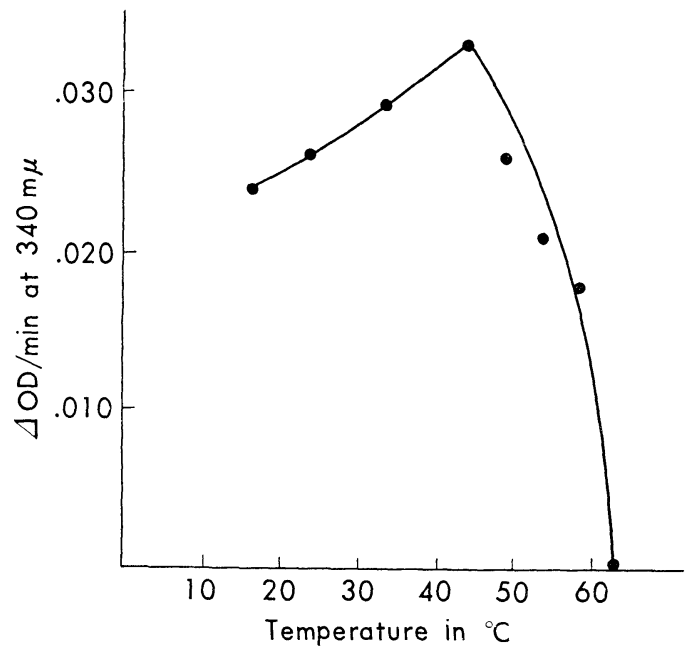

Fig. 9. Effect of heat on the activity of NADP.polyol dehydrogenase. 
The aldoses with the hydroxyl group attached to carbon-2 in the Dglycero-configuration were shown to be the substrates for reduction by the NADP-polyol dehydrogenase of C. albicans.

Sugars without hydroxyl group attached to carbon-2, like the ketosugars, were very poor substrates.

The Michaelis constant obtained for D-xylose suggest that the enzyme would have a low affinity for the substrate.

\section{REFERENCES}

1) M. Bacila and L.A. VeigA, Ciencia e Cultura, 11, 173 (1959).

2) L.A. VeigA and M. BACILA, Ciencia e Cultura, 12, 173 (1960).

3) L.A. VeigA, M. Bacila and B.L. Horecker, Biochem. Biophys. Res. Comm., 2, 440 (1960).

4) L.A. Veiga, Doctor's Thesis. University of Paraná, Curitiba, Brazil (1960).

5) C. Chiang and S.G. Knight, Biochem. Biophys. Res. Comm., 3, 554 (1960).

6) H.G. Hers, Biochim. Biophys. Acta, 37, 120 (1960).

7) V. Moret and S. Sperti, Arch. Biochem. Biophys., 98, 124 (1962).

8) M. Chakravorty, L.A. Veiga, M. Bacila and B.L. Horecker, J. Biol. Chem., 237, 1014 (1962).

9) D. Fossitt, R.P. Mortlock, R.L. Anderson and W.A. Wood, J. Biol. Chem., 239, 2110 (1964).

10) S. Hollmann and O. Touster, J. Biol. Chem., 225, 87 (1957).

11) J. Hickman and G. Ashwell, J. Biol. Chem., 234, 758 (1959).

12) B.M. Szher and B.L. Horecker, Arch. Biochem. Biophys., 116, 117 (1966).

13) L.A. VeigA, J. Gen. Appl. Microbiol., 14, 79 (1968).

14) A. Tiselius, S. Huerten and O. Levin, Arch. Biochem. Biophys., 65, 132 (1956).

15) O. Warburg and W. Christian, Biochem. Z., 310, 384 (1942).

16) P.M. Nossal, Australian J. Exptl. Biol. Med. Sci., 31, 583 (1954).

17) D.P. Burma and B.L. Horecker, J. Biol. Chem., 231, 1053 (1958).

18) E.C. Heath, B.L. Horecker, P.Z. Smyrniotis and Y. Takagi, J. Biol. Chem., 231, 1031 (1958).

19) A. Kornberg, In S.P. Colowick and N.O. Kaplan ed. Methods in Enzymology, Vol. 1. Academic Press, Inc., New York. (1955) p. 441.

20) T. Bücher, Biochem. Biophys. Acta, 1, 292 (1947).

21) W.Z. Mejbaum, Z. Physiol. Chem., 258, 117 (1939).

22) Z. Dische and E. Borenfreund, J. Biol. Chem., 192, 583 (1951).

23) S.M. PARTRIDGe, Biochem. J., 42, 238 (1948).

24) A.H. Mehler, A. Kornberg, S. Glisolia and S. OchoA, J. Biol. Chem., 174, 961 (1948).

25) M. Dixon, Biochem. J., 55, 170 (1953). 